\title{
Egyetemi hallgatók egészségműveltségének vizsgálata
}

\author{
Health literacy survey among university students
}

Szerzők: Végh Balázs, Bíró Éva凹

Debreceni Egyetem, Népegészségügyi Kar, Megelőző Orvostani Intézet, Egészségfejlesztési Tanszék

Beküldve: 2018. 09. 10.

doi: $\quad$ 10.24365/ef.v59i6.357

\begin{abstract}
Összefoglaló:
Bevezetés: Az egészségműveltség fogalma és az azzal kapcsolatos kutatások az elmúlt időszakban kerültek a tudományos érdeklődés középpontjába; ennek hátterében az egészségmúveltség és az egészségi állapot közötti kapcsolat felismerése áll. Jelentősége ellenére e területen még kevés vizsgálat történt hazánkban, tudomásunk szerint egyetemi hallgatók körében pedig korábban egy sem.
\end{abstract}

Módszertan: A jelen közleményben bemutatott vizsgálat a Debreceni Egyetem Népegészségügyi Karának népegészségügyi ellenőr alapszakos hallgatói körében zajlott. Az önkitöltős, papíralapú kérdőív tartalmazott a demográfiai és társadalmi-gazdasági adatokra, szubjektív egészségi állapotra és egészségtudatosságra vonatkozó kérdéseket, továbbá az Európai Egészségmúveltség Felmérésben (HLS-EU) használt, az egészségi ügyekben való boldogulás mértékének megítélését szolgáló kérdéseket is, illetve magába foglalta a funkcionális egészségmúveltség mérésére alkalmas Newest Vital Sign (NVS) teszt magyarra fordított változatát. Az adatok elemzése során khi-négyzet próbát és Fisher-féle egzakt tesztet használtunk az évfolyamok közötti különbségek, illetve logisztikus regressziót az egészségműveltség szintjét determináló tényezők meghatározására.

Eredmények: Az elemzésbe 118 fő válaszait tudtuk bevonni. A HLS-EU-teszt alapján a válaszadók $6 \%$-a az elégtelen, $42 \%$-a a problémás, $44 \%$-a az elégséges és $8 \%$-a a kitűnő egészségmúveltségú kategóriába került. A hallgatók 86\%-ának volt megfelelő, 13\%-uknak limitált és 1\%-uknak inadekvát a funkcionális egészségműveltsége. A negyedéves hallgatók egészségmúveltségének szintje mindkét skálával mérve magasabb volt, mint elsős társaiké, de sem a társadalmi-gazdasági státuszt jellemző paraméterekkel, sem a szubjektív egészségi állapottal nem mutatott összefüggést az egészségmúveltség mértéke.

Következtetés: A vizsgálat úttörő jellege miatt csak korlátozottan adódik lehetőség eredményeink összevetésére más vizsgálatokkal. Egy korábbi hazai vizsgálat eredményeihez képest, ahol 16 éven felüliek körében ugyanezekkel a skálákkal gyűjtöttek adatokat, elmondható, hogy a hallgatók körében magasabb volt a funkcionális egészségmúveltség szintje és a HLS-EU-teszttel mérve alacsonyabb volt az elégtelen kategóriába tartozók aránya, mint az általános lakosság körében.

Kulcsszavak: egészségmúveltség; egyetemi hallgatók 


\begin{abstract}
Summary:
Introduction: The concept of health literacy and the related studies have become the focus of scientific interest recently due to the recognition of the relationship between health status and health literacy. Despite its significance, only few studies have been carried out in this area in our country, and according to our knowledge our study was the first one conducted among university students.

Methodology: A cross-sectional study was carried out among public health inspector students at the Faculty of Public Health University of Debrecen with a self-administered paper-based questionnaire that included items on demographic and socioeconomic data, subjective well-being, health consciousness, and two scales in order to measure self-perceived (European Health Literacy Survey, HLS-EU) and functional (Newest Vital Sign, NVS) health literacy. The chi-square and Fisher-exact test were used in order to analyse the differences between the study years, while the determinants of health literacy were investigated with binary logistic regression.

Results: The answers of 118 students were suitable for data analysis. Based on the results of the HLS-EU scale $6 \%$ of respondents had inadequate, $42 \%$ problematic, $44 \%$ sufficient and $8 \%$ excellent health literacy. The NVS test showed that $1 \%$ of respondents had inadequate, $13 \%$ limited and $86 \%$ adequate health literacy. The level of health literacy was higher among 4th year students compared to freshmen irrespective of the used scale; however there was not any relationship either with socioeconomic status or with health status.

Conclusions: The possibility to compare our results with other studies is limited due to the pioneering approach. Compared to the results of a previous Hungarian study, where the same scales were used to measure health literacy among people above the age of 16 years, it can be stated that the level of functional health literacy was higher among students and the proportion of those who have inadequate health literacy was lower measured by the HLS-EU test.
\end{abstract}

Keywords: health literacy; university students

\section{BEVEZETÉS}

Az egészségmúveltség (health literacy, $\mathrm{HL}$ ) fogalma és az azzal kapcsolatos kutatások az elmúlt időszakban kerültek a tudományos érdeklődés fókuszába, hazánkban pedig csupán néhány évre visszamenően találunk ezzel kapcsolatos publikációkat. Az egészségmúveltség jelentőségét a (nép)egészségügyi szakemberek szempontjából elsősorban azok a vizsgálatok támasztják alá, amelyek kimutatták, hogy annak szintje alapvetően befolyásolja az egészséggel kapcsolatos különböző paramétereket. Így az alacsony $\mathrm{HL}$ összefüggést mutatott a rossz egészségi állapottal és alacsony funkcionalitással, a magas halálozással, a kórházi felvételek nagyobb számával, az orvosi utasítások nem megfelelő betartásával és az egészségügyi szakemberekkel való kevésbé hatékony kommunikációval, magas egészségügyi költségekkel, a prevenciós tevékenységekben való alacsonyabb részvétellel, kedvezőtlenebb egészségmagatartással, és hozzájárult az egészségi egyenlőtlenségek kialakulásához is. ${ }^{1}$

Az egészségmúveltség definiálására több kezdeményezés is született, a legjelentősebbeket egy nemrég megjelent hazai cikk foglalta össze, így azok részletes bemutatásába jelen közlemény keretei között nem bocsátkozunk. ${ }^{2}$ Mindössze a Sørensen és munkatársai által a szakirodalomban talált 17 definíció és 12 konceptuális modell áttekintése után megalkotott integrált modellt szeretnénk röviden ismertetni. ${ }^{3}$ E modell szerint az egészségmúveltség az egészséginformációhoz való hozzáférést, annak megértését, értékelését és alkalmazását jelenti az egészségügyi ellátás, betegségmegelőzés és egészségfejlesztés vonatkozásában az életminőség megőrzése vagy javítása érdekében. ${ }^{2,3}$ Szintjét több, 
köztük társadalmi és környezeti (pl. kultúra, nyelv, társadalmi rendszer), demográfiai (pl. kor, nem) tényezők, valamint a társadalmi-gazdasági helyzet (iskolázottság, foglalkozás, jövedelem) és az általános múveltség is befolyásolja. ${ }^{2,3}$

Az egészségmúveltség mérésére, tekintettel a jelenleg létező sokfajta megközelítésre és a fogalom komplexitására, többféle eszközt is kifejlesztettek. Ezek egy része egészséggel kapcsolatos tudást mér, jellemzően az egészségügyi kifejezések tartalmának és/vagy kiejtésének ismeretével. Mások az egészségügyi kérdésekben való boldogulás mértékét, azaz az önértékelt egészségműveltséget vagy az egészségtárgyú szövegértést, a funkcionális egészségmúveltséget vizsgálják. ${ }^{4}$

Hazánkban eddig mindössze néhány, az általános (nem adott témára fókuszáló) egészségműveltséget vizsgáló felmérés született. Ezek közül az egyik az Európai Unió nyolc tagállamában 2011-ben végzett Európai Egészségmúveltség Felmérésben (European Health Literacy Survey, HLS-EU) is alkalmazott skálákkal történt, így van lehetőség az eredmények összevetésére is. A HLS-EU felmérésben a Sørensen és munkatársai által megalkotott integrált modell vizsgálatára alkalmas, az egészségmúveltséget szubjektív szempontból mérő 47 kérdéses eszközt dolgoztak ki. A kérdésekre adott válaszok alapján a részt vevő európai országok vonatkozásában a lakosság közel fele (47\%) tartozott a korlátozott, $36 \%$ az elégséges és $17 \%$ a kitűnő egészségműveltséggel jellemezhető kategóriába, de az egyes országok között jelentős volt az eltérés. ${ }^{5}$ Ugyanezzel a kérdőívvel 2015-ben történt itthon egy adatfelvétel a 16 éven felüliek körében, amelynek az eredményei alapján a magyar lakosság soraiban valamivel alacsonyabb az egészségmúveltség szintje $\quad(52 \%$ korlátozott, $38 \%$ elégséges, $10 \%$ kitúnő), mint az uniós vizsgálatban kapott átlag. ${ }^{6}$ Ugyanebben a vizsgálatban a Newest Vital Sign (NVS) funkcionális egészségmúveltségi tesztet is felvették, amelynek alapján a részt vevő országok lakosainak 55\%-a, míg a magyarok 69\%-a került a megfelelő kategóriába.,7 Ezenkívül 2015ben egy másik kutatócsoport végzett a felnőtt lakosság egy kisebb mintáján egészségmúveltségfelmérést itthon: ők az NVS-kérdőívvel, valamint a Chew-féle háromkérdéses, önmegítélésen alapuló és a „Rövidített felnőtt funkcionális egészségkompetencia kérdőív" (S-TOFHLA) magyar skálákkal gyújtöttek adatokat. Utóbbi alapján a válaszadók 81,5\%-ának a szövegértése és 83,4\%-ának a számolási alapkészsége adekvát volt. ${ }^{8}$

Tudtunkkal hazánkban, egyetemi hallgatók körében még nem történt egészségműveltségvizsgálat, így kutatásunk fő célja ennek a hiánynak a pótlása volt. Feltételeztük, hogy a magyarországi átlagpopuláció értékeihez képest az általunk választott speciális csoport egészségmúveltsége magasabb lesz.

\section{MÓDSZERTAN}

A vizsgálati populációt a Debreceni Egyetem Népegészségügyi Karának a 2016/2017-es tanév őszi félévében 1-4. évfolyamon tanuló népegészségügyi ellenőr hallgatói alkották ( $n=210)$.

Az adatgyújtés 2016 decemberében tanórák keretében történt egy papíralapú önkitöltős anonim kérdőív segítségével, amely három fő részből állt. Az elsőben demográfiai adatokra (nem, évfolyam) és társadalmi-gazdasági státuszra (szülők iskolai végzettsége, önmegítélés szerinti anyagi helyzet) vonatkozó, míg a másodikban a szubjektív egészségi állapotukra és az egészségtudatosságukra (mennyit tehetnek az egészségükért) vonatkozó kérdések voltak. A harmadik rész az egészségműveltséget két különböző aspektusból vizsgáló skálákat, így az egészségügyi kérdésekben való boldogulás mértékét (szubjektív egészségműveltség) mérő, a bevezetésben már említett HLS-EU felmérésben használt 47 kérdés $^{6}$, illetve a funkcionális egészségmúveltség (egészségi tárgyú szöveg megértése) mérésére alkalmas NVS-kérdőív magyarra fordított változatát tartalmazta, ezzel lehetővé téve az eredmények összehasonlítását.

A HLS-EU értékelése során a nemzetközi vizsgálatban is alkalmazott, alább részletezett protokollt követtük. $^{5}$ A válaszok alapján az összesített egészségértés index, illetve az egészségügyi, prevenciós és egészségfejlesztési alindexek határozhatók meg. A kérdések adott helyzetekre vonatkoznak, amely esetekben egy 1-tól 4-ig terjedő Likert-skálán kell a válaszadónak megítélnie, hogy milyen könnyen vagy nehezen tudna cselekedni az adott helyzetben. Az egyes válaszok alapján a nemzetközi ajánlásnak megfelelően az alábbi képlet segítségével lehet az indexet, illetve annak három alindexét meghatározni: 
index = (átlag-1)×(50/3), ahol az átlag az indexet alkotó itemek átlaga; 1: az átlag elméleti minimuma; 50: a mérőszám választott maximuma; 3: az átlag elméleti terjedelme.

Az egyes indexek kiszámításának feltétele, hogy a válaszok legalább 90\%-a érvényes legyen (a „nem tudom" és az üresen hagyott kérdések nem számítanak annak). Az elért pontszám alapján a következő kategóriák képezhetők: 0-25 pont elégtelen, >25-33 pont problémás, >33-42 pont elégséges, >42-50 pont kitűnő egészségmúveltség. Az elégtelen és problémás kategóriákat együtt korlátozott egészségmúveltségként is szokás nevezni.

A funkcionális egészségműveltség mérésére alkalmas NVS-skála hat kérdésből áll. Itt egy jégkrémes doboz hátulján lévő információk alapján kellett különböző kérdésekre válaszolniuk a hallgatóknak, és minden jó válasz 1 pontot ért. Ezek összegzésével határozható meg az összpontszám, amelynek alapján három kategória hozható létre: 0-1 pont nagy valószínúséggel inadekvát, 2-3 pont valószínúleg limitált, 4-6 pont nagy valószínúséggel megfelelő egészségmúveltséget jelent. ${ }^{9}$

$\mathrm{Az}$ adatok elemzése során khi-négyzet, illetve Fisher-féle egzakt teszttel vizsgáltuk az évfolyamok közötti különbségeket, bináris logisztikus regreszsziót használtunk az egészségmúveltség szintjét determináló tényezők meghatározására és z-próbát az országos adatokkal történő összevetéshez. A logisztikus regresszió elvégzéséhez a két kimeneti változót binárissá kódoltuk át, így a HLS-EU esetén az elégtelen és problémás (korlátozott), illetve elégséges és kitűnő, míg az NVS esetén az inadekvát és limitált kategóriákat vontuk össze.

\section{EREDMÉNYEK}

Összesen 142 hallgató töltötte ki a tesztet, amiből 118 tanuló válaszát elemeztük, mivel az elemzésből az alacsony válaszadási arány miatt a másodéves hallgatókat ( $n=16$, az évfolyam 31\%-a) és a módszertani leírásnál említett korlátok miatt nem értékelhető válaszokat $(n=8)$ kizártuk. Így az első-, harmad- és negyedéves hallgatókra vonatkozóan 75\%-os volt a válaszadási arány. Nemi megoszlást tekintve a karon és a mintában is a nők dominálnak, a válaszadók 93\%-a volt nő.
A szülők iskolai végzettségét tekintve elmondható, hogy az apák 48\%-a, míg az anyák $64 \%$-a rendelkezik legalább érettségivel. Anyagi helyzetét a hallgatók 10\%-a rossznak vagy nagyon rossznak, 66\%-uk átlagosnak és 24\%-uk jónak vagy nagyon jónak ítélte. Egészségi állapotát 64\%-uk ítélte legalább jónak, 32\% kielégítőnek, 4\% rossznak találta. A „Mennyit tehet az egészségéért?" kérdésre a válaszadók 98\%a válaszolta azt, hogy sokat vagy nagyon sokat, egy fő, hogy keveset, és egy fő nem tudta megítélni. A további elemzésből ezt a változót kihagytuk.

\section{Az egészségügyi kérdésekben való boldogulás mértéke: szubjektív egészségmúveltség}

A HLS-EU teszt alapján a válaszadók $6 \%$-ának elégtelen, 42\%-ának problémás, 44\%-ának elégséges és 8\%-ának kitűnő volt az egészségműveltsége az öszszesített egészségértés-index segítségével mérve [1. ábra]. Az 1. ábrán látható az évfolyamonkénti javuló tendencia az első évfolyamtól a negyedik évfolyamig. Míg az első évfolyamos hallgatók egyharmadának volt legalább elégséges az egészségmúveltsége, addig a negyedik évfolyamos hallgatóknál már ez az arány közel 60\%-nak adódott $(p=0,033)$.

Az egészségügyi alindex esetében a hallgatók 44\%ának korlátozott, 44\%-ának elégséges és $12 \%$-ának kitűnő volt az egészségmúveltsége [2. ábra], a 4. évfolyamosok körében alacsonyabb volt a korlátozott egészségmúveltséggel jellemezhetők aránya a tanulmányaikat kezdő hallgatókhoz képest $(p=0,053)$.

A prevenciós alindex vonatkozásában a hallgatók 45\%-a tartozott a korlátozott egészségmúveltség kategóriájába, 40\%-uknak elégséges és 15\%-uknak kitűnő volt az egészségmúveltsége [3. ábra], a végzősök körében kisebb volt a korlátozott egészségmúveltségűek aránya az 1 . éves hallgatókhoz képest $(p=0,002)$.

$\mathrm{Az}$ egészségfejlesztési alindex esetében volt a legmagasabb a korlátozott egészségműveltség kategóriájába tartozók aránya (56\%), egyharmaduknak volt elégséges és 11\%-uknak kitűnő az egészségmúveltsége, valamint az évfolyamok összehasonlításakor sem látható annyira markáns trend, mint a többi index esetében $(p=0,169)$. [4. ábra] 
1. ábra: Az egészségügyi kérdésekben való boldogulás mértéke az összesitett egészségértés-index alapján, évfolyamonkénti bontásban

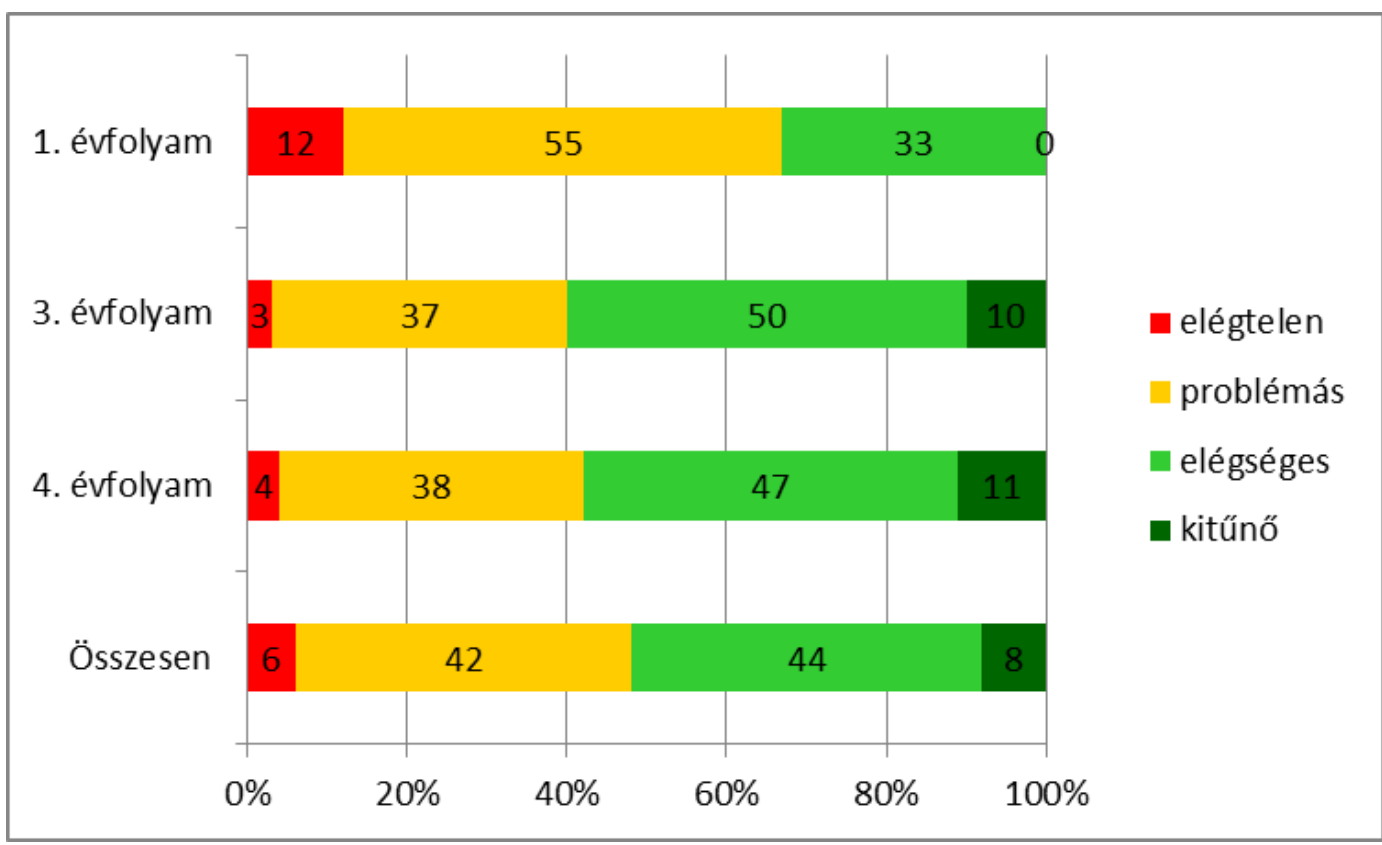

Forrás: saját szerkesztés

2. ábra: Az egészségügyi kérdésekben való boldogulás mértéke az egészségügyi alindex alapján, évfolyamonkénti bontásban

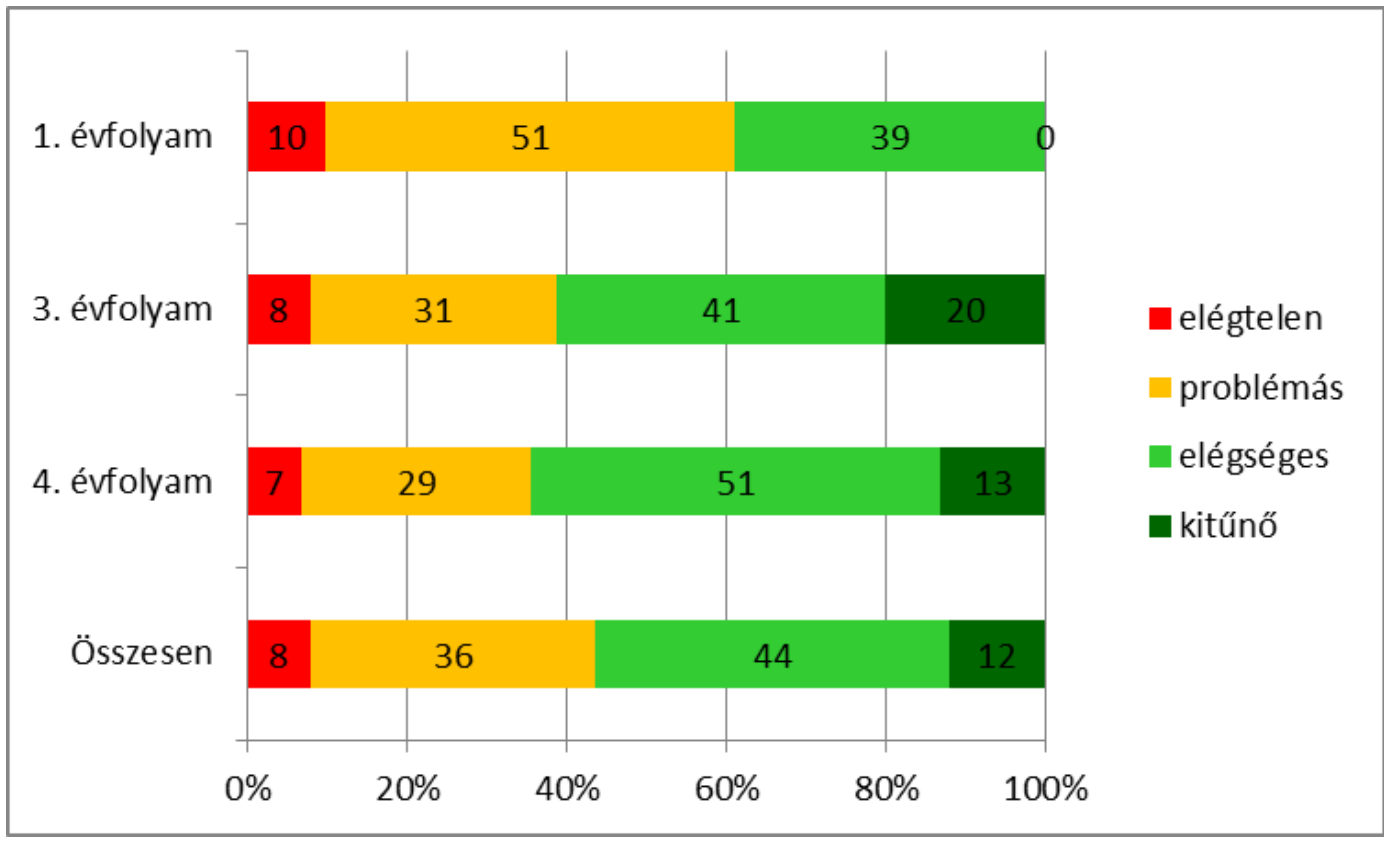

Forrás: saját szerkesztés 
3. ábra: Az egészségügyi kérdésekben való boldogulás mértéke a prevenciós alindex alapján, évfolyamonkénti bontásban

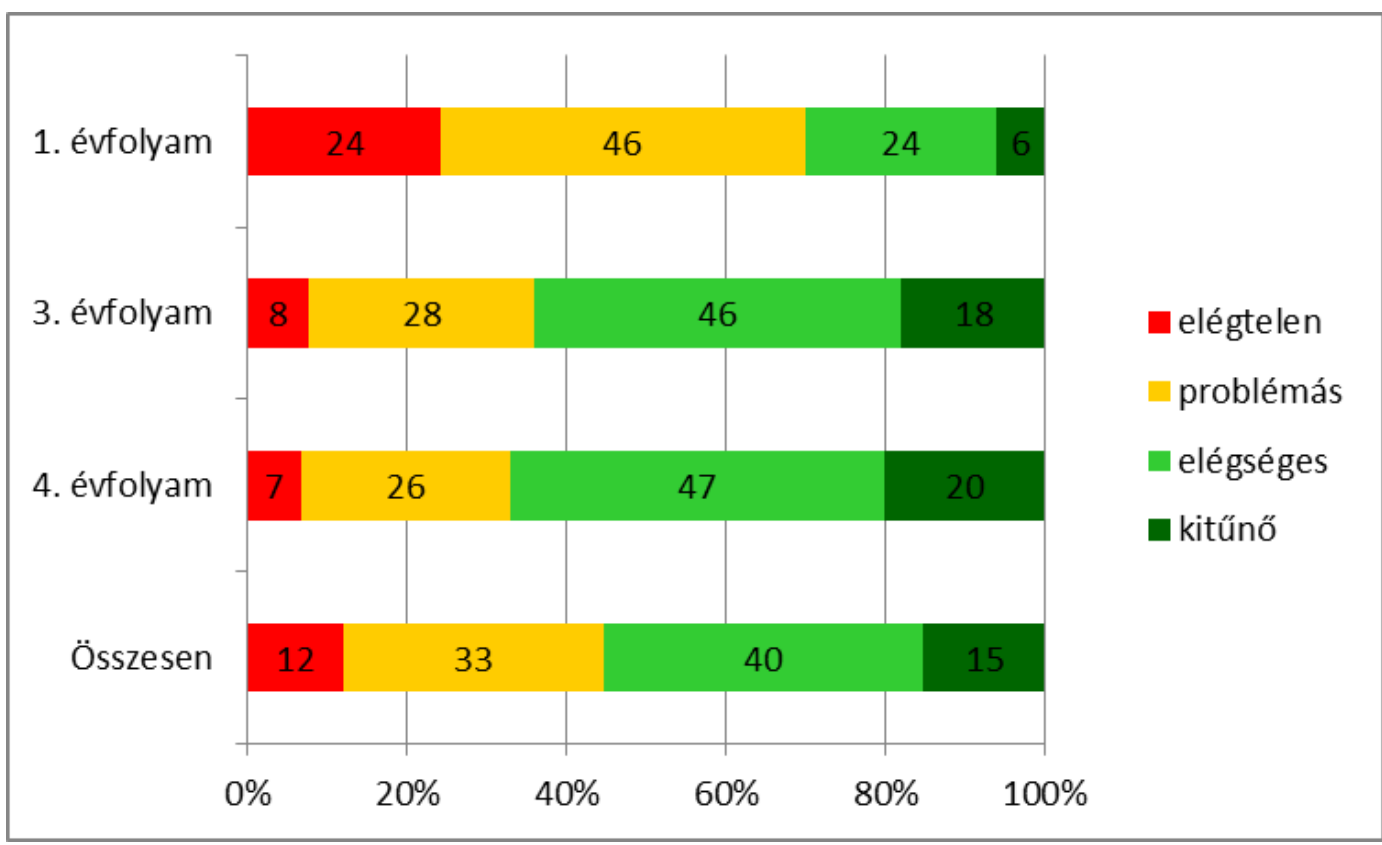

Forrás: saját szerkesztés

4. ábra: Az egészségügyi kérdésekben való boldogulás mértéke az egészségfejlesztési alindex alapján, évfolyamonkénti bontásban

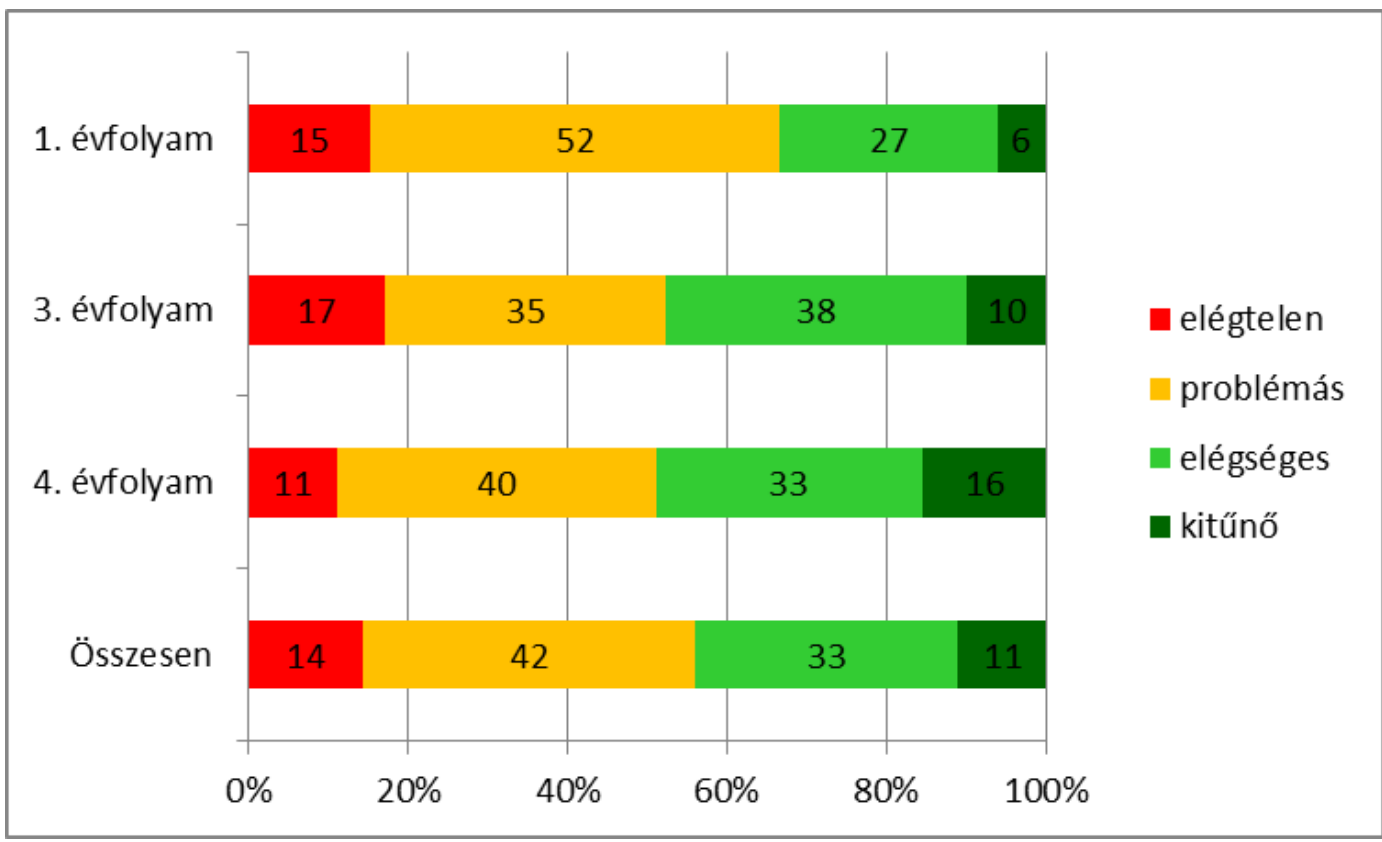

Forrás: saját szerkesztés 
A szubjektív egészségműveltség összefüggése más paraméterekkel

A bináris logisztikus regresszió eredménye szerint a szubjektív egészségműveltség az általunk vizsgált paraméterek - így a nem, évfolyam, szülők iskolai végzettsége, önmegítélés szerinti anyagi helyzet, szubjektív egészség és funkcionális egészségműveltség - közül csak az évfolyammal mutatott összefüggést. A magasabb szubjektív egészségmúveltség esélye a végzős hallgatók körében közel 3,5-szeres volt az elsős hallgatókhoz képest. [1. táblázat]

1. táblázat: A szubjektiv egészségmüveltség (HL) összefüggése más paraméterekkel

\begin{tabular}{|c|c|c|}
\hline Magyarázó változók & $\begin{array}{c}\text { Esélyhányados } \\
\text { (95\%-os megbízhatósági tartomány) }\end{array}$ & p-érték \\
\hline Nem (referencia: nő) & $0,22(0,04-1,28)$ & 0,093 \\
\hline \multirow[t]{2}{*}{ Évfolyam (ref.: I. év) } & $2,92(1,00-8,48)$ & 0,049 \\
\hline & $3,49(1,22-10,04)$ & 0,020 \\
\hline \multicolumn{3}{|l|}{ Anya iskolai végzettsége (ref.: max. szakmunkás) } \\
\hline középiskola & $1,78(0,71-4,49)$ & 0,221 \\
\hline fóiskola/egyetem & $2,84(0,87-9,25)$ & 0,083 \\
\hline \multicolumn{3}{|l|}{ Apa iskolai végzettsége (ref.: max. szakmunkás) } \\
\hline középiskola & $0,67(0,28-1,62)$ & 0,373 \\
\hline főiskola/egyetem & $0,73(0,19-2,83)$ & 0,654 \\
\hline \multicolumn{3}{|l|}{$\begin{array}{l}\text { Önmegitélés szerinti anyagi helyzet (ref.: rossz/na- } \\
\text { gyon rossz) }\end{array}$} \\
\hline átlagos & $0,78(0,21-2,89)$ & 0,715 \\
\hline jó/nagyon jó & $0,95(0,22-4,10)$ & 0,941 \\
\hline Szubjektív egészség (ref.: rossz/kielégítő) & $1,83(0,79-4,20)$ & 0,154 \\
\hline Funkcionális HL (ref.: inadekvát/limitált) & $1,77(0,51-6,19)$ & 0,372 \\
\hline
\end{tabular}

Forrás: saját szerkesztés

\section{Funkcionális egészségműveltség}

Az NVS-kérdésekre adott válaszok alapján, ahogy az 5. ábran is látszik, a hallgatók funkcionális egészségmúveltsége 86\%-ban megfelelőként, 13\%-ban limitáltként és 1\%-ban inadekvátként volt jellemezhető. Évfolyam szerinti bontásban vizsgálva az adatokat e skála esetében is látszik a pozitív tendencia, a megfelelő egészségmúveltségúek aránya az 1 . évfolyamosok körében mért 70\%-kal szemben $91 \%$ a 4 . évesek körében $(p=0,021)$.
A funkcionális egészségműveltség összefüggése más paraméterekkel

A funkcionális egészségmúveltség az általunk vizsgált paraméterek - így a nem, évfolyam, szülők iskolai végzettsége, önmegítélés szerinti anyagi helyzet, szubjektív egészség és szubjektív egészségműveltség - közül a bináris logisztikus regresszió eredménye szerint, a szubjektív egészségmúveltség esetén kapott eredményekkel összhangban, csak az évfolyammal volt kapcsolatban. A magasabb funkcionális egészségmúveltség esélye a negyedéves hallgatók körében közel hatszorosa volt a tanulmányaikat kezdő hallgatókénak. [2. táblázat] 
5. ábra: A funkcionális egészségmüveltség mértéke a hallgatók körében, évfolyamonkénti bontásban

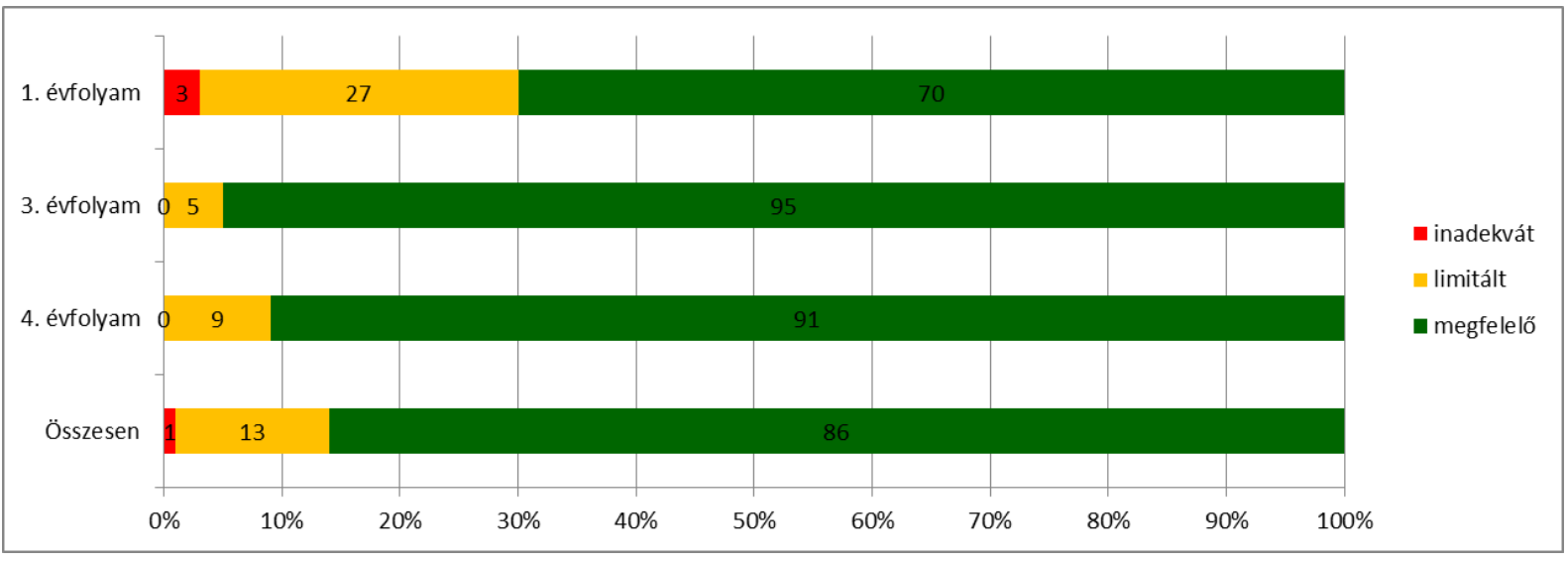

Forrás: saját szerkesztés

2. táblázat: A funkcionális egészségmúveltség (HL) összefüggése más paraméterekkel

\begin{tabular}{|c|c|c|}
\hline Magyarázó változók & $\begin{array}{l}\text { Esélyhányados } \\
\text { (95\%-os megbízhatósági tartomány) }\end{array}$ & p-érték \\
\hline Nem (referencia: nő) & $0,18(0,02-1,41)$ & 0,102 \\
\hline Évfolyam (ref.: I. év) & $10,61(1,73-65,16)$ & 0,011 \\
\hline IV. & $5,98(1,35-26,55)$ & 0,019 \\
\hline \multicolumn{3}{|l|}{ Anya iskolai végzettsége (ref.: max. szakmunkás) } \\
\hline középiskola & $0,88(0,21-3,67)$ & 0,865 \\
\hline főiskola/egyetem & $0,56(0,10-3,02)$ & 0,499 \\
\hline \multicolumn{3}{|l|}{ Apa iskolai végzettsége (ref.: max. szakmunkás) } \\
\hline középiskola & $2,35(0,56-9,87)$ & 0,244 \\
\hline fóiskola/egyetem & $1,59(0,22-11,56)$ & 0,643 \\
\hline \multicolumn{3}{|l|}{$\begin{array}{l}\text { Önmegítélés szerinti anyagi helyzet (ref.: rossz/na- } \\
\text { gyon rossz) }\end{array}$} \\
\hline átlagos & $0,47(0,05-4,68)$ & 0,515 \\
\hline jó/nagyon jó & $0,25(0,02-2,89)$ & 0,267 \\
\hline Szubjektív egészség (ref.: rossz/kielégítő) & $0,96(0,28-3,36)$ & 0,95 \\
\hline Funkcionális HL (ref.: inadekvát/limitált) & $1,82(0,49-6,66)$ & 0,369 \\
\hline
\end{tabular}

Forrás: saját szerkesztés 


\section{MEGBESZÉLÉS}

Az általunk vizsgált egyetemi hallgatók esetében az egészségügyi kérdésekben való boldogulás mértékét mérő, önmegítélésen alapuló skála alapján a hallgatók 52\%-a tartozott az elégséges vagy kitűnő kategóriába, a funkcionális egészségműveltsége pedig 86\%-uknak volt megfelelő.

Az egészségfejlesztési alindex kivételével minden esetben elmondható, hogy a magasabb évfolyamra járó hallgatók egészségműveltsége egyértelműen meghaladta az elsős hallgatók egészségműveltségét. Tekintettel arra, hogy a hallgatók egészségtudományi képzésben vesznek részt, nem meglepő, hogy a képzés előrehaladtával az egészségműveltségük is pozitív irányba változik. Az egészségfejlesztési alindex esetében vélhetően azért nem volt annyira markáns a változás, mert az adatfelvétel az egészségfejlesztés oktatásának elején történt.

Tekintettel arra, hogy hazánkban egyetemisták körében még nem történt hasonló kutatás, csak korlátozottan adódik lehetőség eredményeink más vizsgálatokkal való összevetésére. A bevezetésben már említett, 16 éven felüliek körében zajlott hazai kutatásban ugyanezekkel a skálákkal gyűjtöttek adatokat, és így van lehetőség az eredmények összehasonlítására. ${ }^{6,7}$ Ennek alapján elmondható, hogy a hallgatók körében a HLS-EU-teszttel mérve alacsonyabb volt az elégtelen kategóriába tartozók $(p<0,001)$ és magasabb a funkcionális egészségmüveltség szempontjából a megfelelő kategóriába tartozók aránya $(p<0,001)$, mint az általános lakosság körében. [6. ábra és 7. ábra] Az Európai Unió nyolc országában elvégzett HLS-EU-felmérés összesített eredményeihez képest szintén kedvezőbb volt a hallgatók körében az elégtelen kategóriába sorolhatók aránya a szubjektív egészségmúveltség esetén ( $p=0,034)$, valamint a funkcionális egészségmüveltség vonatkozásában magasabb arányban kerültek a megfelelő kategóriába, mint az uniós átlag $(p<0,001) .^{5}$ [6. ábra és 7. ábra] A szubjektív és a funkcionális egészségmúveltség vonatkozásában a megfelelő kategóriába sorolhatóak arányában talált különbség a hallgatók között összecseng a hazai mintán tapasztalt eredményekkel, de a HLS-EUfelmérés eredményeiből nem lehet erre vonatkozóan egyértelmű következtetést levonni. ${ }^{5,6,7}$

[6. ábra és 7. ábra]

6. ábra: Szubjektiv egészségműveltség az összesitett egészségértés-index alapján az Európai Egészségműveltség Felmérésben (HLS-EU) részt vett országokban, Magyarországon és a népegészségügyi hallgatók körében

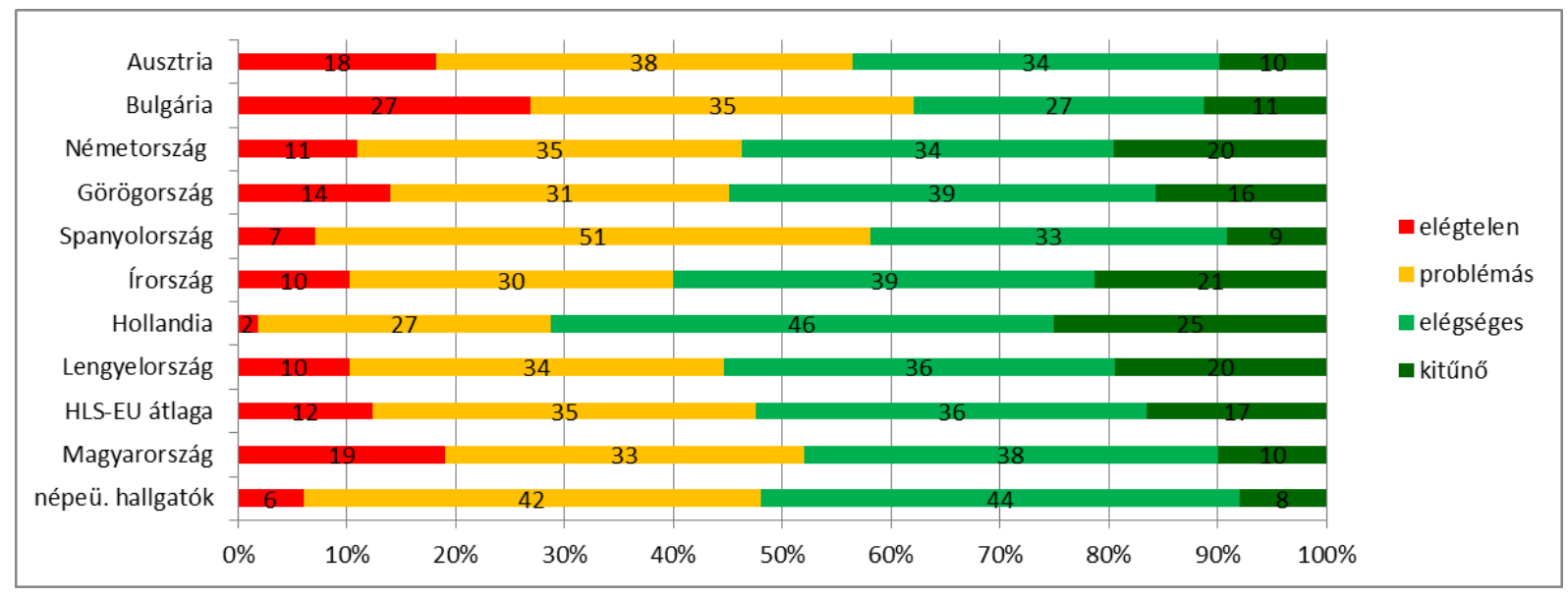

Forrás: saját szerkesztés a HLS-EU ${ }^{5}$ és a magyarországi felmérés ${ }^{6}$ adatai alapján 
7. ábra: Funkcionális egészségmüveltség az Európai Egészségmüveltség Felmérésben (HLS-EU) részt vett országokban, Magyarországon és a népegészségügyi hallgatók körében

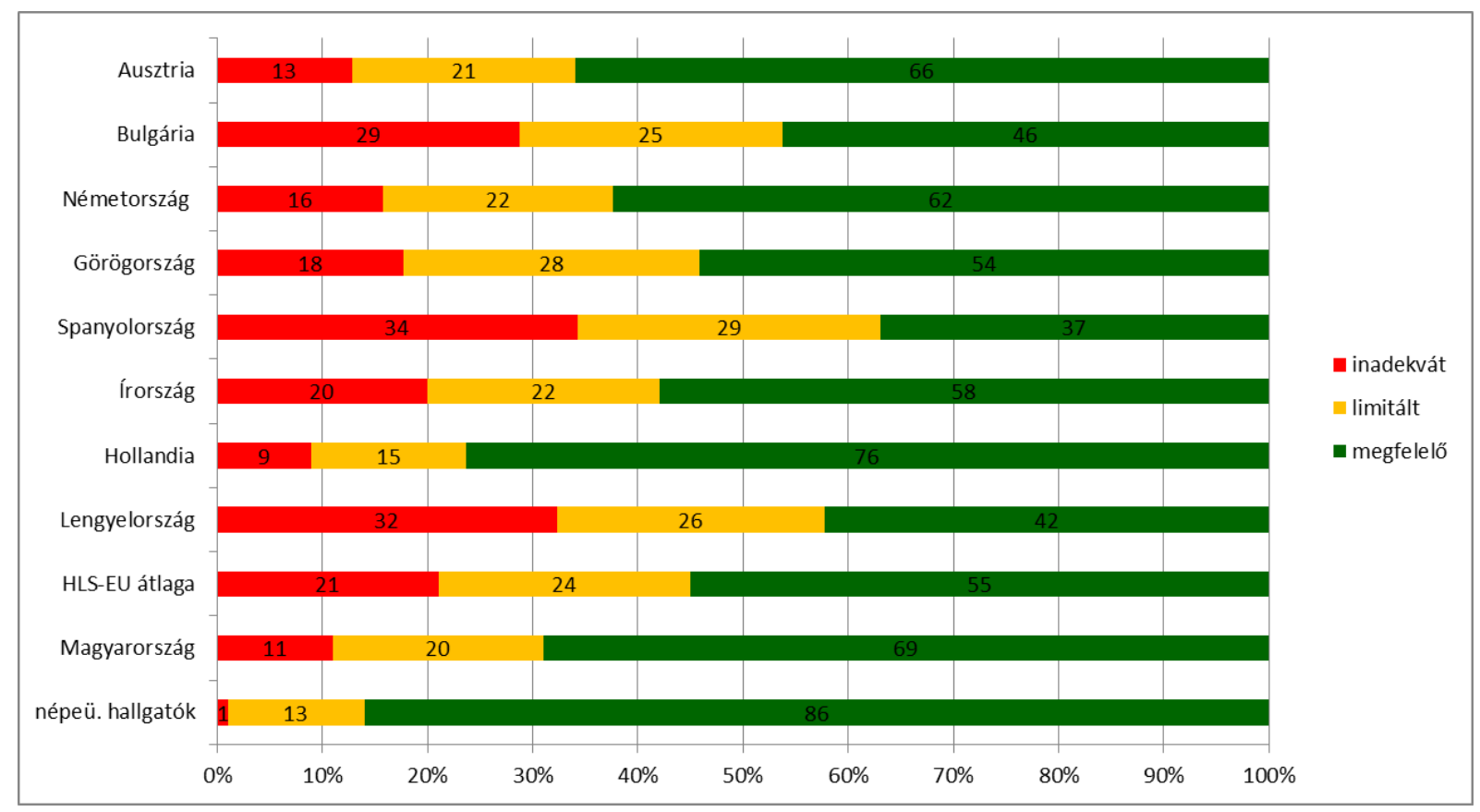

Forrás: saját szerkesztés a HLS-EU ${ }^{5}$ és a magyarországi felmérés ${ }^{7}$ adatai alapján

Vizsgálatunk limitációjaként elmondható, hogy a kapott eredményeket nem tudjuk a karon tanuló összes népegészségügyi ellenőr hallgatóra általánosítani, mert a másodéves hallgatókat az alacsony válaszadási arány miatt kizártuk az elemzésből. A vizsgálati populációt magasabb iskolai végzettségű és zömében egészséges fiatal felnőttek alkották, ami hatással lehet a kapott eredményekre.

\section{KÖVETKEZTETÉSEK}

A következtetéseket befolyásolja az, hogy milyen mérőeszközt választunk az egészségmúveltség mérésére, hiszen a szubjektív és a funkcionális egészségmúveltség vonatkozásában nagyon eltérő eredményeket kaptunk.

Mindazonáltal mindkét változó vonatkozásában elmondható, hogy a felsőbb évesek egészségmúveltsége kedvezőbb, mint az első évfolyamos hallgatóké, és összességében a hallgatók egészségmúveltsége jobb, mint a hazai 16 éven felüli populációra jellemző érték. Ez utóbbi összefüggésben lehet a mintába bekerülők életkorával, nemével és iskolai végzettségével, hiszen a fiatalok, nők és a magasabb iskolai végzettségúek körében általában magasabb az egészségmúveltség.

Ugyanakkor az egészségmúveltség sem a társadalmi-gazdasági helyzettel, sem a szubjektív egészségi állapottal nem mutatott összefüggést ebben a speciális alcsoportban. Ennek egyik lehetséges magyarázata, hogy iskolai végzettség szempontjából homogén a minta, és a társadalmigazdasági tényezők közül vélhetően ez befolyásolja leginkább mind az általános, mind az egészségműveltség szintjét. Az egészségi állapotát pedig közel kétharmaduk jónak ítélte a válaszadóknak, így kevésbé volt differenciálható a minta e paraméter alapján.

\section{KÖSZÖNETNYILVÁNITTÁS}

Szeretnénk köszönetet mondani mindazoknak a hallgatóknak, akik kitöltötték a kérdőívet.

A kutatást a GINOP-2.3.2-15-2016-00005 számú projekt támogatta. A projekt az Európai Unió támogatásával, az Európai Regionális Fejlesztési Alap társfinanszírozásával valósult meg. 


\section{HIVATKOZÁSOK}

\footnotetext{
${ }^{1}$ Dodson S, Good S, Osborne RH. Health literacy toolkit for low- and middle-income countries: a series of information sheets to empower communities and strengthen health systems. World Health Organization, Regional Office for South-East Asia, New Delhi, 2015. http://apps.searo.who.int/PDS DOCS/B5148.pdf (Elérve: 2018. 09. 09.) ${ }^{2}$ Csizmadia P. Az egészségmúveltség definíciói. Egészségfejlesztés. 2016;57(3):41-44. doi:http://dx.doi.org/10.24365/ef.v57i3.68.

${ }^{3}$ Sørensen K, Van den Broucke S, Fullam J, et al. Health literacy and public health: a systematic review and integration of definitions and models. BMC Public Health. 2012;25:12-80. doi: 10.1186/1471-2458-12-80

${ }^{4}$ Szabó P, Kósa K. Egészségmúveltség a magyar népesség körében, Orvostovábbképző Szemle. 2016;23(2):66-72.

${ }^{5}$ HLS-EU Consortium. Comparative report of health literacy in eight EU member states. The European Health Literacy Survey HLS-EU (First revised and extended version), 2012.

${ }^{6}$ Koltai JA, Kun E. A magyarországi egészségértés nemzetközi összehasonlításban. Egészségfejlesztés. 2016;57(3):3-20. http://dx.doi.org/10.24365/ef.v57i3.62

${ }^{7}$ Koltai JA, Kun E. Az egészségértés gyakorlati mérése Magyarországon és nemzetközi összehasonlításban Orv. Hetil. 2016;157(50):2002-2006. https://doi.org/10.1556/650.2016.30563

8 Papp-Zipernovszky O, Náfrádi L, Schulz PJ, et al. „Hogy minden beteg megértse!” - Az egészségműveltség (health literacy) mérése Magyarországon. Orv Hetil. 2016;157(23):905-915.

doi: 10.1556/650.2016.30412

${ }^{9}$ Weiss BD, Mays MZ, Martz W, et al. Quick Assessment of Literacy in Primary Care: The Newest Vital Sign. Ann Fam Med. 2005;3(6):514-522. doi:10.1370/afm.405
} 